\title{
Renewable energy innovation in Europe: Energy efficiency analysis
}

\author{
Svitlana Kolosok $^{1, *}$, Iuliia Myroshnychenko ${ }^{1}$, Halyna Mishenina ${ }^{1}$, and Inessa Yarova $^{2}$ \\ ${ }^{1}$ Sumy State University, Department of Management, 40007, 2 Rymskogo-Korsakova St., Sumy, Ukraine \\ ${ }^{2}$ Sumy State University, Department of International Economic Relations, 40007, 2 Rymskogo-Korsakova St., Sumy, Ukraine
}

\begin{abstract}
In this manuscript, we investigate the importance of renewable energy innovation for achieving inclusive and sustainable goals and the state's energy security. Emphases in research are made on investigation the effect of regulatory policies and fiscal incentives on achieving renewable energy targets. Exploiting energy data for 28 European countries over the period 1990-2018, we assess the relationship between the volumes of renewable energy and energy efficiency. The statistical analysis we performed in Python. Our results indicate that the share of energy from renewable positively correlates with all energy efficiency indicators except energy productivity.
\end{abstract}

\section{Introduction}

Energetics as complex system deals with the generation, transmission, distribution and utilization of fuel and energy resources. That process requires the constant improvements to decrease energy consumption and shift to use of renewable energy sources, which are gradually replacing traditional fossil energy resources. Renewable energy innovations include different areas: technology (development of new solutions to reduce costs and increase efficiency); business (invention and development of new business models and services); politics (development the pillars for a competitive business environment). Moreover, $R \& D$ in renewable energy should contribute to the achievement of the SDG 7 and the Paris Agreement, fight against climate change and reflect the overall (or aggregate) ecological and economic effect.

According to Directive 2012/27/EU of the European Parliament and of the Council on energy efficiency, [1] 'energy efficiency' is defined as the ratio of output of performance, service, goods, or energy, to input of energy. Furthermore, 'energy efficiency improvement' is considered as increase in energy efficiency due to technological, behavioral, and/or economic changes. More precise, energy efficiency means the reduction in the energy consumption per unit or product amount without decreasing of life standard and production/service amount and quality. Majority of international energy programs and frameworks concentrate on the priority of energy innovation to develop sources of renewable energies. For instance, EU's climate and energy targets for 2030 includes a commitment to achieve decrease of greenhouse gas emissions by $40 \%$ (from 1990 levels), increase 32\% share for renewable energy and get at least $32.5 \%$ improvement in energy efficiency [2]. The International Renewable Energy Agency (IRENA) assesses that, the accelerated deployment of renewables and energy efficiency can achieve $90 \%$ of the emissions reductions by 2050 [3].

The computational complexity for assessment of efficiency of renewable energy poses challenges for methodological and practical research as well as for applied modern science.

\section{Literature review}

Development of renewable and alternative energy sources are the most crucial aspect of economic growth and a factor of ensuring the country's energy security for the long term [4]. For many countries, the development of renewable energy is an essential contribution to achieving economic and political goals, such as reducing dependence on natural gas imports and diversifying energy sources. Worth to mention, the importance of managing renewable energy innovation for inclusive and sustainable economic growth [5]. Numerous publications in Scopus and Web of Science database proves that renewable energy innovation is a promising area in modern science, that reveal the positive effects of increasing energy production through renewable energy resources. At the same time, researches face a problem in obtaining data about renewable energy innovations. The majority of empirical analyses provide an assessment of factors influencing the development of renewable energy innovations rather than evaluate the general effectiveness of renewable energy innovations.

As underline by Gökgöz et al., the importance of innovation promotion and the significant $R \& D$ investment on renewable energy innovations and efficiency will have resulted in technological diffusion

\footnotetext{
* Corresponding author: kolosok@management.sumdu.edu.ua
} 
and knowledge spillover within European Union countries [6].

Popp in [7] estimates the strong positive impact of energy prices on patenting activity (as well as the development of new energy technologies) for environmentally friendly technologies. Wu"stenhagen et al. raise a problem of social acceptance of renewable energy innovation as dimensions of socio-political, community and market acceptance [8]. The authors emphasize on the importance of support among key stakeholders for the development and implementation of renewable energy innovations.

Authors in $[9,10]$ consider biogas as the most perspective alternative resources and prove economic attractiveness for investment. Lyeonov et al. evaluate that green investment stimulates the growth of GDP per capita by $6.4 \%$ and the increase of renewable energy by $5.6 \%$ in the total final energy consumption [11]. Similar results get Marcel in [12]. The author estimates bidirectional causality running from electricity consumption and economic growth.

Mentel et al. [13] develops a model for electricity pricing on a local level and analyze factors impact on the formation of long-term incentives for switching to the production of green energy.

\subsection{Renewable energy innovation}

Renewable energy innovation and technologies are emerging with potential social, economic, and environmental effect. The International Energy Agency (IEA) [14] uses the following classification of renewable energy technologies as specified by the novelty of their development (see Figure 1).

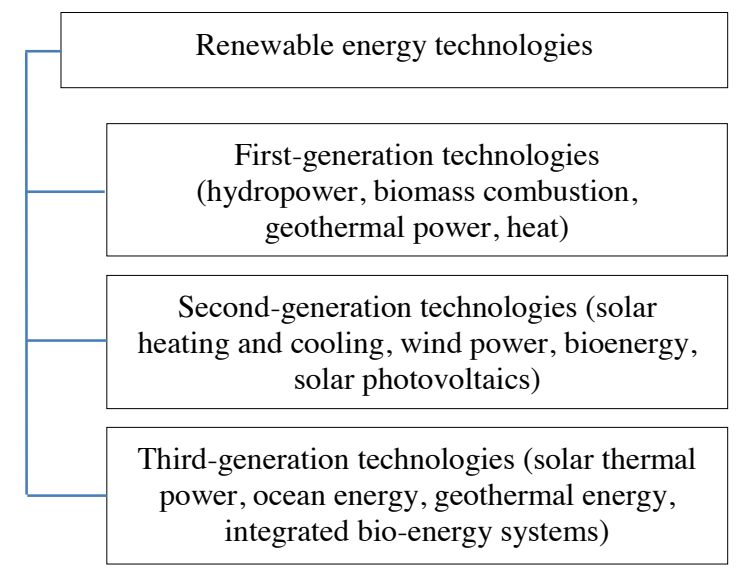

Fig. 1. Generations of renewable energy technologies

\subsection{Financial incentives for renewable energy innovation}

Renewable energy innovations have a risk associated with high capital investment costs. Capital expenditures are usually affected by local economic conditions at the time of construction of the installation, such as financing conditions, depreciation, and, potentially, the type of investor or source of financing. Nevertheless, renewable energy sources play an important role in the energy balances of many countries of the world, both developed and developing.

In most developing countries, the spread of renewable energy sources is hindered by high initial investments and a long payback period. To stimulate investment and guarantee stability for producers of energy resources, the government develops measures to regulate energy tariffs, signing long-term agreements on the purchase of electricity, and develop competitive mechanisms as auctions and tendering schemes. In this way, governments mobilize R\&D investment in renewable energy technologies to increase its costs competitiveness.

Authors in $[15,16]$ analyses the advantages of applying green bonds for financing a variety of green projects and resources saving and environmental protection activities. Authors define economic, social, political and environmental benefits of green bonds market, in particular for energy innovation.

The conception of financial cooperation and coopetition for realizing small-scale development projects are noteworthy in the context of fiscal stimulus for energy projects $[17,18]$.

Institutional quality play significant role in successful implementation of energy innovations in the developing countries. Dkhili, H. estimates the positive effect of increasing institutions quality on the level of environmental performance [19].

As for developed countries, energy-saving projects leads to a significant increase in investment costs and shifts from long-term investments with slow payback periods to profitable short-term endowment. According to REN 21 in 2018 [20] most common regulatory policies for achieving the renewable energy targets in countries with high income were: feed-in tariff/ premium payment, biofuel blend obligation/mandate and net metering/ billing. Less frequent, tradable REC, tendering and electric utility quota obligation/RPS tools were used for stimulation renewable energy projects.

Fiscal incentives and public financing policies for gaining renewable energy targets should to be taken into account. Reductions in sales, energy, $\mathrm{CO}_{2}$, VAT or other taxes, tax incentives, public investment, loans, grants, capital subsidies or rebates as key drivers for innovation. Also, investment or production tax credits and energy production payment should be used in national policy or tender framework for achieving the renewable energy targets. The positive experience of the EU countries has shown that among the various factors affecting the level and prospects for the development of renewable energy innovations, the government's economic incentives play a decisive role.

\section{Data and methodology}

\subsection{Data}

In our work, we used several data sources to analyze the relationship between the volumes of renewable energy and energy efficiency in the EU-28. Firstly, based on Eurostat and the European Environment Agency's data, 
we evaluated energy efficiency targets, which are declared in the Europe 2020 strategy and implemented by Directive 2012/27 / EU on energy efficiency. The energy efficiency targets values for 2020 and 2030 are linked to primary energy and final energy consumption (MTOE). From 1990 to 2018 (with reference period from January to December), annual data is available for analysis on the websites of these organizations. We also used the index of energy efficiency (index of energy consumption), the Ener_ef_i, with the base year 2005 .

Secondly, the overall EU-28 share of energy from renewable source innovations (RES, \%) was collected from the Eurostat website. The RES time series covered from 2004 to 2018 on the Eurostat website.

Thirdly, for our analysis, additional performance indicators were used: energy productivity (euro per KGOE) and energy intensity of GDP in chain-linked volumes (KGOE per thousand euro). We also extracted this data from the Eurostat website.

\subsection{General methodology}

In this paper, we were guided by the definitions and methodology described in the Directive 2012/27/EU and Directive (EU) 2018/2002. According to these directives, in crucial energy efficiency targets are primary and final energy consumption.

Primary energy consumption (PEC) represents the gross available energy minus non-energy use.

Gross available energy (gross inland energy consumption) in the EU-28 means the sum of the total inland energy demand of the Member States (1).

$$
\mathrm{GAE}_{s j}=P E P_{s j}+R E P_{s j}+T E I_{s j}+S E C_{s j}-T E E_{s j}-E B_{s j}(1)
$$

where $\mathrm{GAE}_{s j}$ - gross available energy of $j$-country for $i$-period; $P E P_{s j}$ - primary energy production of $j$ country for $i$-period; $R E P_{s j}$ - recovered energy products of $j$-country for $i$-period; $T E I_{s j}$ - total energy imports of $j$-country for $i$-period; $S E C_{s j}-$ stock energy change of $j$ country for $i$-period; $T E E_{s j}$ - total energy exports of $j$ country for $i$-period; $E B_{s j}$ - energy bunkers of $j$-country for $i$-period.

Final energy consumption means the energy supplied to all final consumers (2).

$$
F E C_{s j}=F E C I_{s j}+F E C T_{s j}+F E C H_{s j}+F E C S_{s j}+F E C A_{s j}(2)
$$

where $F E C_{s j}$ - final energy consumption of $j$-country for $i$-period; $F E C I_{s j}$ - final energy consumption industry of $j$-country for $i$-period; $F E C T_{s j}-$ final energy consumption transport of $j$-country for $i$-period; $\mathrm{FECH}_{s j}$ - final energy consumption households of $j$ country for $i$-period; $F E C S_{s j}$ - final energy consumption services of $j$-country for $i$-period; $F E C A_{s j}-$ final energy consumption agriculture of $j$-country for $i$-period.

Also, essential indicators of energy efficiency are indicators such as share of energy from renewable sources, energy intensity, and productivity, final-toprimary energy consumption ratio.
The share of energy from renewable is calculated as follows (3):

$$
R E S_{s j}=R E S-E_{s j}+R E S-T_{s j}+R E S-H \& C_{s j}+R E S-N T_{s j}
$$

where $R E S-E_{s j}$ - share of gross final consumption of electricity from RES of $j$-country for $i$-period, $\%$; RES$T_{s j}$ - share of gross final consumption of energy from RES in transport of $j$-country for $i$-period, \%; RES$H \& C_{s j}$ - share of gross final consumption from RES for heating and cooling of $j$-country for $i$-period, \%; RES$N T_{s j}$ - share of net transfer of RES to other Member States and $3^{\text {rd }}$ countries of $j$-country for $i$-period, $\%$.

The RES indicator can indirectly transfer the share of renewable energy innovations of substituted fossil and/or nuclear fuels in a region for a given period.

Energy intensity of GDP in chain-linked volumes (2010) is calculated as units of energy per unit of GDP (4). It is essential to find energy intensity to understand economic changes not only for a region as a whole but also for its components: households $(E I+H)$, industry $(E I I)$, services $\left(E I \_S\right)$, and transport $(E I-T)$.

$$
E I \_G D P_{s j}=\mathrm{GAE}_{s j} / G D P_{s j}
$$

where EI_GDP $P_{s j}$ - energy intensity of GDP in chain linked volumes of $j$-country for $i$-period; $\operatorname{GDP}_{s j}-$ gross domestic product at market (current) prices of $j$-country for $i$-period.

Energy productivity $(E P)$ represents the output that is produced per unit of gross available energy (5).

$$
E P_{s j}=G D P_{s j} / \mathrm{GAE}_{s j}
$$

For the calculation of final-to-primary energy consumption ratio $\left(F 2 P_{-} E C\right)$ necessary to find the share between final energy consumption and primary energy consumption.

The statistical analysis in this paper was performed in Python using Numpy, Pandas, Scikit-learn, Seaborn modules, etc.

\section{Results and discussion}

The changes in the energy sector have been actively taking place in recent years in Europe. There is an influential 'green conservative' and the 'green liberal' movement that promotes transformations in environmental policies. These changes apply to all economic areas and, in particular, in the energy sector. Countries voluntarily committed themselves to the 2015 Paris Agreement, which calls for the implementation of reforms based on innovative solutions to achieve sustainable development goals.

If we look at the situation in Europe, then countries have entirely different approaches to the effectiveness of innovation and renewable energy sources. According to the Eurostat, energy efficiency also varies within the EU.

Regarding the primary and final energy consumption, there is a general trend in EU-28 of a decrease in 
indicator values since 2005. This trend is also attributable to existing renewable energy targets. The EU did not reach a $20 \%$ energy savings rate in 2018 . The total primary energy consumption in the EU should be decreased by $4.6 \%$ primary and final energy consumption by $3.5 \%$ to meet the 2020 target. The final energy consumption indicator since 2016 began to grow despite the drop in primary energy consumption in the EU. Therefore, it is doubtful that it will be possible to achieve the goals by 2020 .

However, since primary energy consumption is falling and the final energy consumption is growing, this is also can be considered as a positive trend in economic efficiency. It is possible to reduce energy losses and optimize consumption by introducing innovative technologies such as smart meters and smart grids. Although a linear relationship previously described the general relation between indicators, this situation is now changing somewhat (Fig. 2).

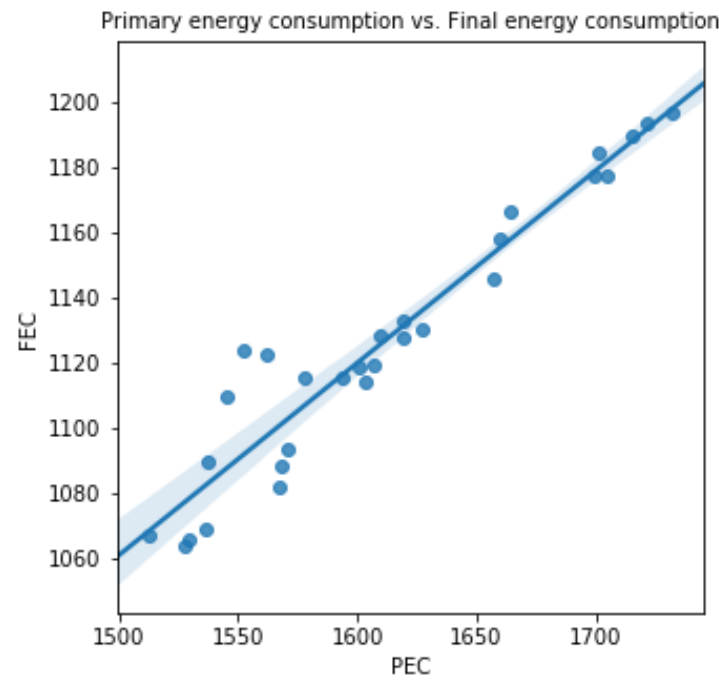

Fig. 2. The relationship between primary and final energy consumption EU-28 (Source: Conducted by authors based on the Eurostat information, ec.europa.eu/eurostat)

The change path of the final-to-primary energy consumption ratio $\left(F 2 P_{-} E C\right)$ is positive (Fig. 3). Since 2011, there has been a leap in reducing energy consumption losses. European countries narrowed the gap between primary and final energy consumption. Nevertheless, the 2020 target value was not achieved in 2018.

The same controversial situation is with a share of renewable energy sources in total consumption. According to the Eurostat, the percentage of renewable energy in the EU has been growing since 2004 in EU-28. In 2018, this index was $17.98 \%$ of final gross consumption. And from 2016 to 2018, the indicator's growth rate did not exceed $2.88 \%$, and the 2020 target of $20 \%$ RES share may not be reached.

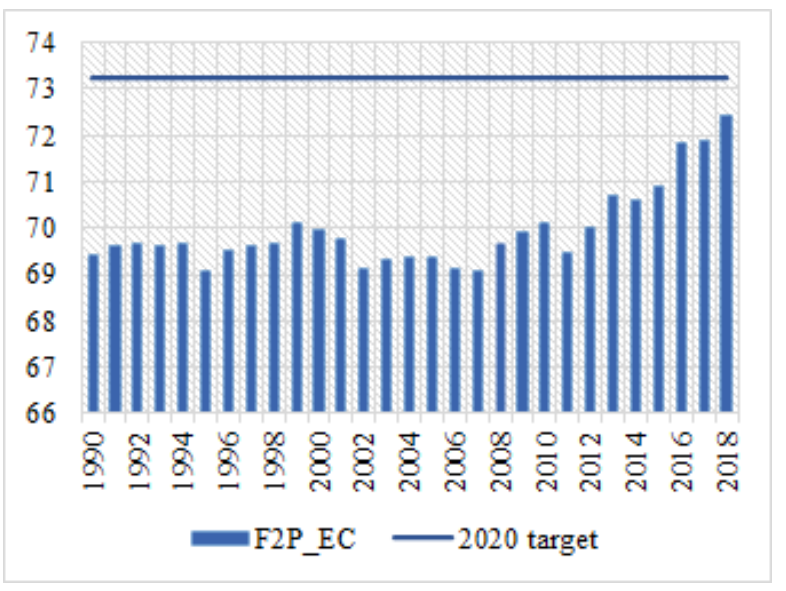

Fig. 3. The final-to-primary energy consumption ratio (F2P_EC) EU-28 (Source: Conducted by authors based on the Eurostat information, ec.europa.eu/eurostat)

If we consider together all the indicators of energy efficiency, we can see their close relationship (Fig. 4). The RES share positively correlates with all indicators except energy productivity $(E P)$, which may indicate the need for further innovative developments to reduce the cost of renewable energy sources.

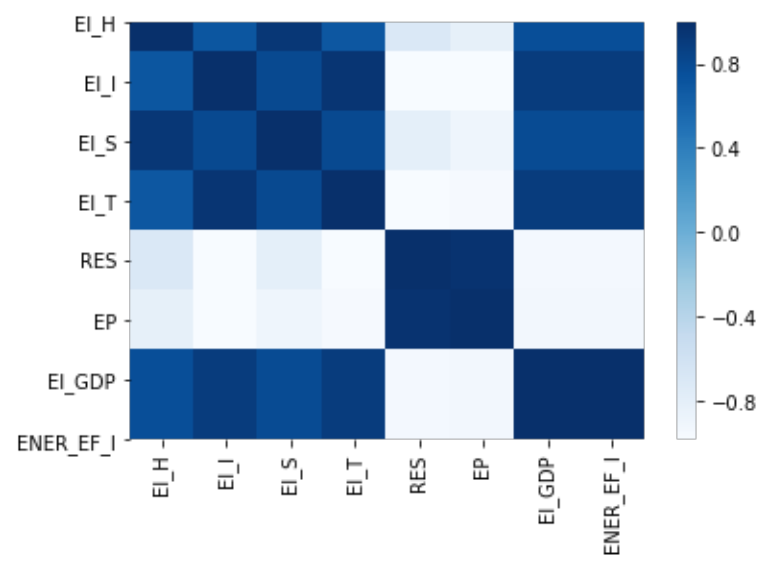

Fig. 4. Heat map of energy efficiency indicators EU-28 (Source: Conducted by authors based on the Eurostat, ec.europa.eu/eurostat, and the EEA information, www.eea.europa.eu)

\section{Conclusion}

The development of renewable energy innovation systems is one of the most crucial aspects of socioeconomic growth and energy security as well as tools for achieving inclusive and sustainable goals. Renewable energy innovation is cost-competitive in many countries, but their large-scale distribution can lead to operational challenges. The authors also focus on the need to implement additional fiscal incentives and public financing policies for achieving renewable energy targets. In addition to payment for capacity, it is necessary to distribute such financial instruments as investment subsidies and grants, fiscal (tax) discounts, biofuel blend obligation, net metering/ billing and 
subsidizing the cost of credit. Without these support measures, renewable energy innovations may be problematic for some countries, especially in the current context of limited access to credit. All stakeholders (policymakers, regulators, technology providers, utilities, etc.) should work in collaboration to achieve costeffective energy sector.

Our study concentrates on the assessment of the relationship between the volumes of renewable energy and energy efficiency in the EU-28. Our results indicate that variables related to energy from renewables contain valuable information to explain the energy efficiency in the EU-28.

Acknowledgment. Authors appreciate the copyright holder: (C) European Commission, Eurostat, and to the source of the extracted data which is Eurostat @ https://ec.europa.eu/eurostat; (c) the European Environment Agency (EEA), the owner of copyrights and database rights in the website@ https://www.eea.europa.eu/.

This work was supported by the Ministry of Education and Science of Ukraine (the project No. 0119U100766 'The optimization model of smart and secure energy grids building: an innovative technologies of enterprises and regions ecologisation').

\section{References}

1. Directive 2012/27/EU of the European Parliament and of the Council of 25 October 2012 on energy efficiency, $\quad$ https://eur-lex.europa.eu/legalcontent/EN/TXT/PDF/?uri=CELEX:32012L0027\&f rom=EN, last accessed 2020/05/29

2. 2030 climate \& energy framework, https://ec.europa.eu/clima/policies/strategies/2030_e n, last accessed 2020/05/29.

3. IRENA. Renewable energy innovation: accelerating research for a low-carbon future (2017)

4. T. Vasylyeva, S. Pryymenko, Environmental economic assessment of energy resources in the context of ukraine's energy security. Actual probl. econ. 160(1), 252-260 (2014)

5. I. Kendiukhov, M. Tvaronaviciene, Managing innovations in sustainable economic growth. Mark. and manag. of innov. 3, 33-42 (2017) http://doi.org/10.21272/mmi.2017.3-03

6. F. Gökgöz, M. T. Güvercin, Energy security and renewable energy efficiency in EU. Renew. Sust. Energ. Rev., 96, 226-239 (2018) https://doi.org/10.1016/j.rser.2018.07.046

7. D. Popp, Induced innovation and energy prices. Am. Econ. Rev., 92 (1), 160-180 (2002)

8. R. Wustenhagen, M. Wolsink, M. J. Burer, Social acceptance of renewable energy innovation: An introduction to the concept. Energy Policy, 35(5), 2683-2691 (2007)

9. Y. Yevdokimov, O. Chygryn, T. Pimonenko, O. Lyulyov, Biogas as an alternative energy resource for Ukrainian companies : EU experience. Innov.
Market., $\quad$ 14(2), 7-15

https://doi.org/10.21511/im.14(2).2018.01

10. J. Cebula, O. Chygryn, S.V. Chayen, T. Pimonenko, Biogas as an alternative energy source in Ukraine and Israel: current issues and benefits. Int. J. Environ. Technol. Manag., 21(5-6), 421-438 (2018) DOI: 10.1504/IJETM.2018.100592

11. S. Lyeonov, T. Pimonenko, Y. Bilan, D. Štreimikiene, G. Mentel, Assessment of green investments' impact on sustainable development : Linking gross domestic product per capita, greenhouse gas emissions and renewable energy. Energies 12(20), 1-12 (2019) https://doi.org/10.3390/en12203891

12. D. Marcel, Electricity consumption and economic growth Nexus in the Republic of Benin. SocioEcon. Challeng. 3(2), 63-69 http://doi.org/10.21272/sec.3(2).63-69.2019

13. G. Mentel, T. Vasilyeva, Y. Samusevych, S. Pryymenko, Regional differentiation of electricity prices : Social-equitable approach. Int. J. Environ. Technol. Manag. 21(5-6), 354-372 (2018) DOI: 10.1504/IJETM.2018.100583

14. Fuels and technologies International Energy Agency. https://www.iea.org/fuels-andtechnologies, last accessed 2020/05/29

15. O. Chygryn, T. Pimonenko, O. Luylyov, A. Goncharova, Green bonds like the incentive instrument for cleaner production at the government and corporate levels : Experience from EU to Ukraine. Journal of Environmental Management and Tourism 9(7), 1443-1456 (2018) https://doi.org/10.14505//jemt.v9.7(31).09

16. T. Pimonenko, Y. Bilan, J. Horák, L. Starchenko, W. Gajda, Green brand of companies and greenwashing under sustainable development goals. $\begin{array}{llll}\text { Sustainability } & \mathbf{1 2}(4), & 1679 & \text { (2020) }\end{array}$ https://doi.org/10.3390/su12041679

17. Y. Petrushenko, N. Kostyuchenko, Y. Danko, Conceptual framework of local development financing in UNDP projects in Ukraine. Actual probl. econ.159(9), 257-263 (2014)

18. H. Shvindina, Coopetition as an emerging trend in research: Perspectives for safety \& security. Safety 5(3), 61 https://doi.org/10.3390/safety5030061

(2019)

19. H. Dkhili, Environmental performance and institutions quality : evidence from developed and developing countries. Mark. and manag. of innov., 3, 333-244 http://doi.org/10.21272/mmi.2018.3-30

20. The Renewables 2019 Global Status Report (GSR 2019) https://www.ren21.net/wpcontent/uploads/2019/05/gsr_2019_full_report_en.p df 